\title{
Development Boneythings Store E-Commerce Application for Selling Muslimah Clothes
}

\author{
Nurainun \\ Software Engineering Technology, \\ Agriculture Polytechnic of \\ Samarinda, 75131, Indonesia \\ Nurainun1000@gmail.com
}

\author{
Yulianto (i)* \\ Software Engineering Technology, \\ Agriculture Polytechnic of \\ Samarinda, 75113, Indonesia \\ yulianto.javacom@gmail.com \\ *Corresponding Author
}

\author{
Emil Riza Putra \\ Software Engineering Technology, \\ Agriculture Polytechnic of \\ Samarinda, 75131, Indonesia \\ Emilriza92@gmail.com
}

Submitted: 2021-10-03; Revised: 2021-10-03; Accepted: 2022-02-10; Published: 2022-03-01

\begin{abstract}
The background of this research is because it can make it easier for a seller to introduce or market their products, and this website, can save costs and be more efficient. Therefore, the purpose of this study is to provide convenience to store owners and consumers in obtaining information purchasing products sold by the Web-Based Boneythings Store. The tools used in drawing the system model are in the form of use cases, activity diagrams, class diagrams, sequence diagrams. To implement this application, sales and orders are needed, supporting components are needed to work properly. These components include using the PHP programming language and for data storage using a MySQL database. The design of this system is expected to help and overcome existing problems so that it can be useful for interested parties.
\end{abstract}

Keywords - Laravel, PHP, Website, Information System, Sales.

\section{INTRODUCTION}

In this era of globalization, information technology is developing very rapidly and rapidly according to the growing human needs. Humans are increasingly using technology to make it easier to carry out activities in everyday life. At this time we have known the name of the internet. With the internet, it can facilitate communication and delivery of the information needed without knowing distance and time. One example of Online Store Sales is "E-commerce Web-Based Online Sales at Adhizzshop Stores using Woocommerce" an individual business entity engaged in the sale of clothing for children. In developing sales, apart from selling products offline, they also sell products online. The business process that occurs at this store is that customers can come to place orders via WhatsApp and Facebook (Hamdani, 2020).

Boneythings shop is an online shop that is engaged in the sale of clothing. The products sold by Boneythings Shop are all produced from Indonesia. There are various kinds of products such as Bergo Hijab, Pashmina, Mukena. With new models that are always updated all the time. With this Information System, Online Shops are competing to advance or improve Web-Based Information Systems. With this Web Information System, it can make it easier for a salesperson to introduce or market their products, and with this, they can save costs and be more efficient.

The Sales System used at the Boneythings Store currently still uses Instagram facilities because it doesn't have E-commerce yet, so sales are still minimal. In recording sales transaction data, the Boneythings Store is still manual, so errors often occur in reporting. By using the Instagram facility as a means of selling, the scope of sales and promotions is still small because only people who join the Boneythings Store Instagram account can see their products.

The solution proposed to overcome the problem at the Boneythings Store to build a sales business is Ecommerce. E-commerce is a trade transaction contact between sellers and buyers using internet media. The advantage gained by using transactions through Ecommerce is to increase revenue by using online sales which are cheaper and also operational costs such as paper, catalog printing.

Based on the above background, the researcher formulation the problem How to design and create a Web-Based Boneythings Store E-commerce Application, How to implement Web-Based Boneythings Store Ecommerce Application, Can the Boneythings Store Ecommerce Application help Store Owners and Consumers in making transactions easier.

The purpose of the E-commerce Application for selling product equipment at the Boneythings Store is: To design and create Web Based Boneythings Store Ecommerce Applications, To implement Web-Based Boneythings Store E-commerce Application, To provide convenience to store owners and consumers in obtaining information on purchasing products sold by the WebBased Boneythings Store.

The results of this study can be used to make it easier to analyze and manage the amount of merchandise inventory needed to minimize the cost of storing inventory due to too much stock.

\section{LITERATURE REVIEW}

\section{A. Literature Study}

(Burhanudin, 2017) entitled E-commerce Applications on Web-Based Khairunniswa Stores, the purpose of this 
research is to design an E-commerce-Based Information System at Khairunniswa Shops to assist and increase sales to be able to place orders online and provide information Latest products sold to customers on the Webpage. Khairunniswa Store is a store that is engaged in the sale of Muslim clothing such as robes, hijab khimar, mukena, and others.

(Abimanyu, 2020) entitled Business To Customers Ecommerce Application at UD. Glorious Rays. UD. Sinar Mulya is a company engaged in the sale of office equipment. The Sales System used today is the Conventional System, namely, the buyer must come directly to the UD Store. Sinar Mulya to see the products offered. The purpose of this study is that buyers can view products on a computer screen, access the information, order, and pay with the available options. Buyers can save time and costs because they don't have to come to a place or make transactions so they can make decisions quickly from their seats.

(Yusriyanah \& Prihandi, 2019) and Ifan Prihandi entitled Web-Based Photoshop E-commerce Application with Interment Method. The purpose of this research is to make it easier for customers to access and get the information they need anytime and anywhere and can expand product marketing and can book services via the Web.

(Haerulah \& Ismiyatih, 2017) entitled E-commerce Application for Sales of Wedding Souvenirs. The purpose of this study is to provide an Electronic Wedding Souvenir Seller Application at the XYZ Store. So that customers can get information quickly, and can make online shopping transactions. The research method used is SDLC (System Development Life Cycle) using MYSQL PHPMyadmin modeling.

(jusmawati, 2017) entitled E-commerce Applications at the Merauke Ifa Stand. The purpose of the research carried out is to analyze and identify the current Sales System and identify the Information System needs needed by customers and design a User-friendly and interactive Web or E-commerce Application in increasing sales and transaction effectiveness.

\section{B. Theoretical Foundation}

An information system is a combination of the activities of people who use technology, hardware, software, to support operations. In a very broad sense, the term information system is often used to refer to the interaction between people, algorithmic processes, data, and technology that collects, transforms, and disseminates information within an organization (Puspitasari, 2016).

(Budyastuti, 2019) also stated that: "Information System is a system within an organization that contains a collection of procedures and provides certain outside parties with the necessary reports".

Based on the expert opinion above, the authors conclude that the Information System is the result of data processing is a necessary system and transaction processing needs and a system within an organization that contains a collection of procedures.
E-commerce is electronic commerce, the marketing of goods or services with an electronic system via the internet. In this case, E-commerce has content that involves data/systems/management that is run automatically. This industry will involve transactions such as fund transfers, online marketing, buying and selling, and so on. E-commerce is part of E-business, where the scope of E-business is wider, not just commerce but also includes collaborating with business partners, customer service, job vacancies, and others.

Sales are the lifeblood of a company because from sales profit can be obtained as well as an effort to attract. Consumers who are endeavored to find out their attractiveness so that they can find out the results of the products produced.

In making a sale, there is a transfer of ownership rights over goods and services from the seller to the buyer accompanied by the delivery of compensation from the recipient of the goods or services in return for the delivery. Several types of sales, namely:

a) Trade Selling

Sales can occur if manufacturers and traders allow retailers to improve the distribution of their products.

b) Missionary Selling

The process of increasing sales by encouraging buyers to buy goods from dealers.

c) Technical Selling

The process of increasing sales by providing advice and advice to buyers of goods and services.

d) New Business Selling

Efforts to open new transactions with prospective buyers like insurance companies do.

e) Responsive Selling

Where every salesperson can react to requests as well as buyers through route driving and retailing.

Programming is the process of writing, testing and improving and maintaining the code that builds a computer. This code is written in different programming languages. The purpose of programming is to create a program that can perform a calculation or work in accordance with the wishes of the program. Programming is an art in using one or more algorithms that are interconnected by using a particular programming language so that it becomes a computer program (Puspitasari, 2016).

\section{RESEARCH METHODS}

A. Tools and Materials

The tools used in the research of Boneythings Store E-commerce Applications and Web-Based Boneythings Store Stocks are as follows:

1. Asus laptop (intel inside) CPU Intel Celeron N4000, up to $2.6 \mathrm{~Hz}$, RAM 4GB HDD $1 \mathrm{~TB}$.

2. Sublime Text

3. PHP

4. (Browser) Google Chrome

5. Balsamiq

6. Xampp

7. StartUML

8. Draw.Io 


\section{B. Research Procedure}

Writing this thesis using research procedures in system design which is used to describe several stages in the development process. The research procedure was carried out in several stages, as shown in the following picture 1 .

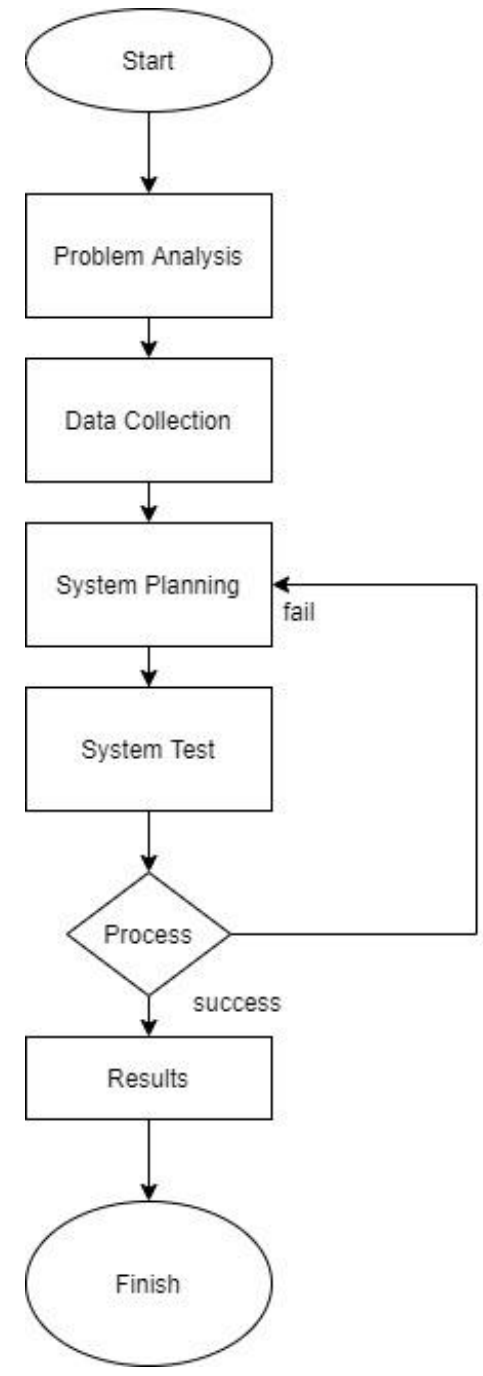

Picture 1. Research Procedure

The steps taken in this research are as follows:

1. Problem Analysis

This stage is the initial stage to determine the research process carried out. This stage is done so that researchers can find problems that occur based on the background and also the formulation of the problem.

2. Data Collection

Literature study is a search for theoretical references that are relevant to the case or problem found, Interview At this stage the data collection technique is carried out through face-to-face and direct question and answer researchers with resource persons, Field Study At this stage the data is taken directly at the research site.

3. System Design

a) Use Case Diagram

Use case are used during the system development stage. Use case diagrams to describe the expected functionality of a system (Apriliah et al., 2021). As seen in the following picture 2 .
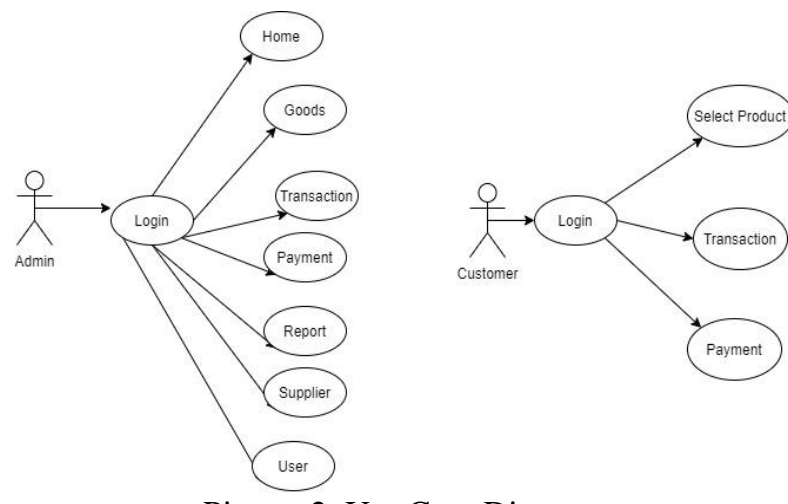

Picture 2. Use Case Diagram

b) Activity Diagram

Activity diagram describe the flow of activities in a system that will be created, how an activity starts, decisions that may occur and the activity end (Novita et al., 2019). As seen in the picture 3.

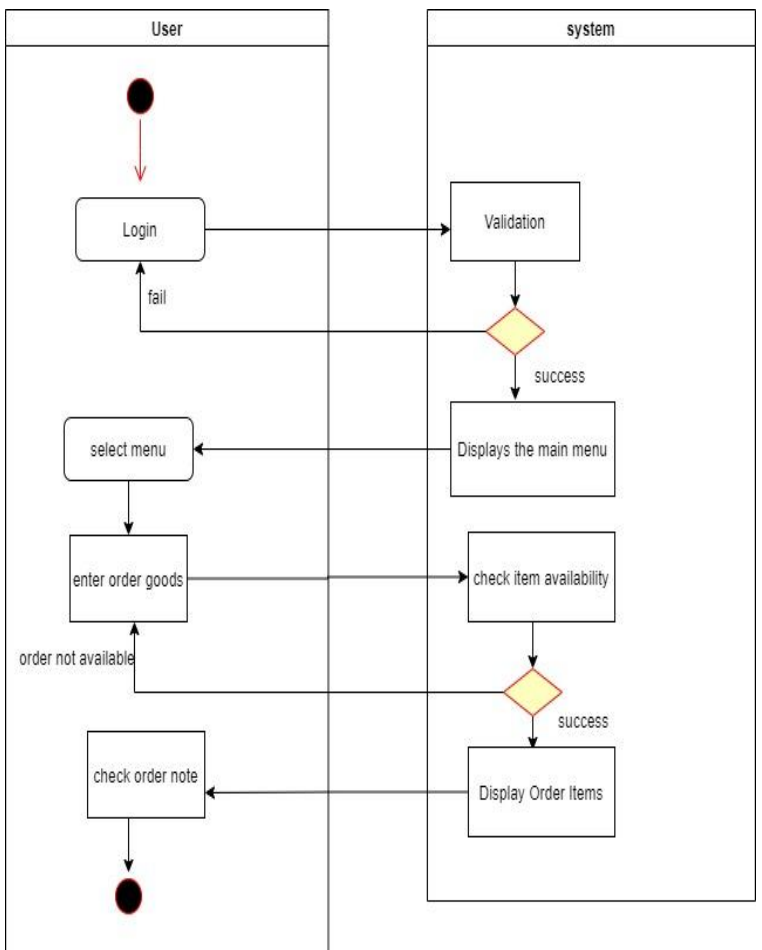

Picture 3. Activity Diagram

c) Sequence Diagram

Sequence Diagram are used to explain the flow of messages from one object to another sequentially (sequentially) from the first user starts until it produces the expected output (Novita et al., 2019). As seen in the picture 4. 


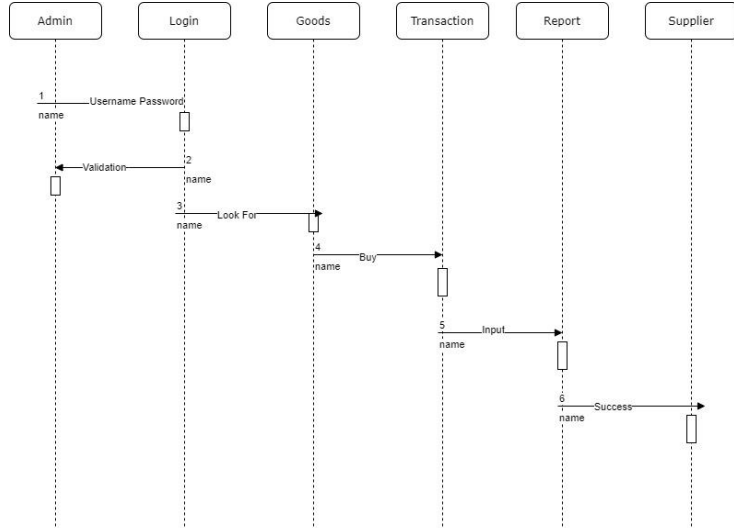

Picture 4. Sequence Diagram

\section{RESULTS AND DISCUSSION}

The results of the development of an e-commerce application for selling Muslim equipment at a web-based Boneythings store have nine menus for admin and seven menus for users, namely goods, sales, purchases, suppliers, users, reports, payments. This application is made using the PHP programming language and the Laravel 6 framework.

1. Admin Menu Display

The following is a display of the results of an ecommerce application selling Muslim equipment at a web-based Boneythings store that has been created:

a) Login Page

The login page to enter or start the application can be seen in the following picture 5 .

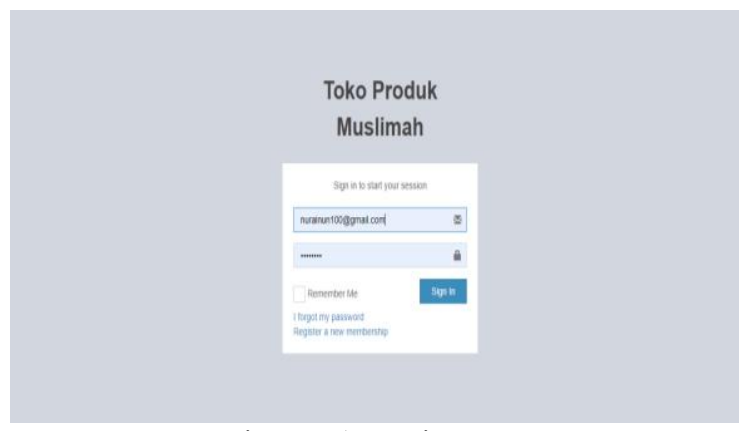

b) Admin Homepage

Picture 5. Login Page

The Home page displays the initial view and several pages that appear after Login which can be seen in the following picture 6 .

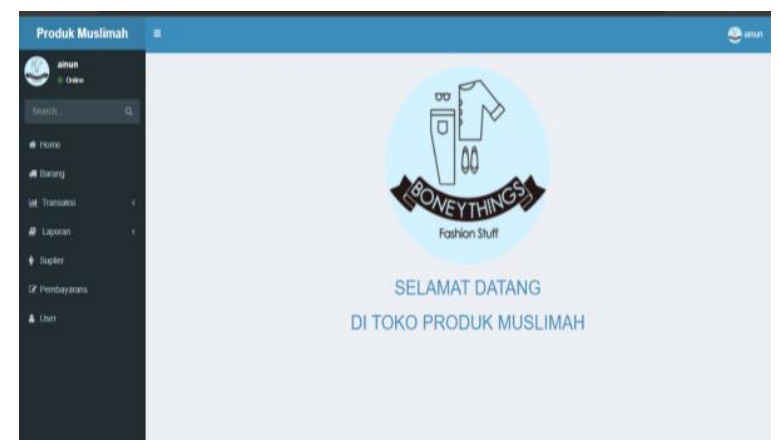

Picture 6. Admin Homepage c) Sales Input Page

The sales data input page displays several forms that can be filled in by the admin to add sales data, these can be seen in the following picture 7 .

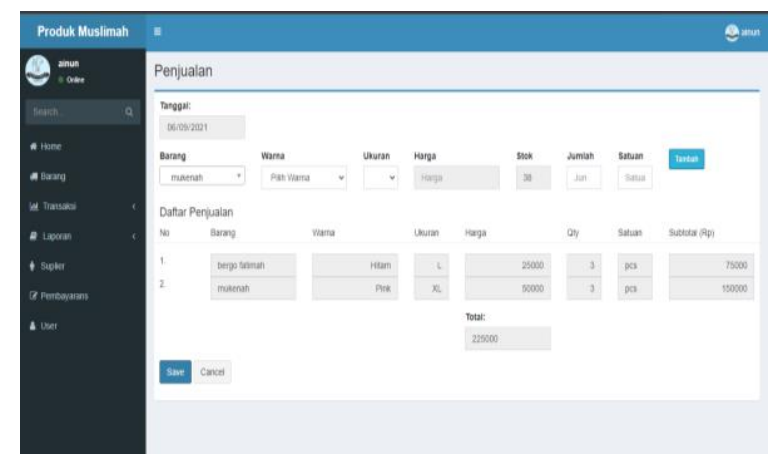

Picture 7. Sales Input Page

d) Sales Data Page

This page displays the data that the admin has previously input. The sales page has several actions such as adding new data, deleting data, editing data and viewing data which can be seen in the following picture 8.

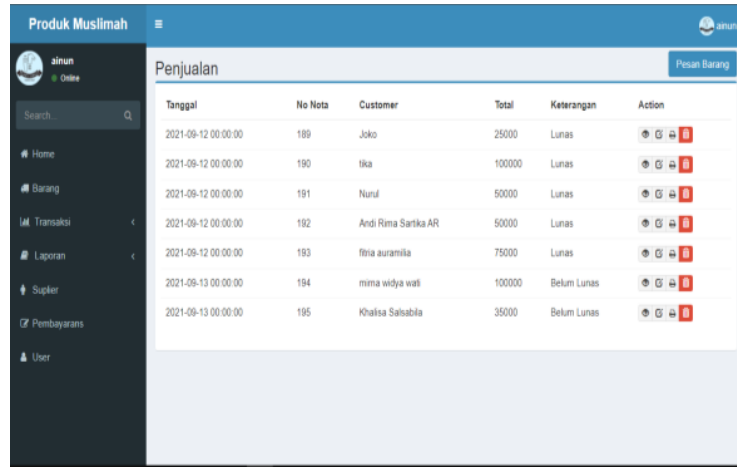

Picture 8. Sales Data Page

e) Purchase Input Page

The purchase input page displays several from that the admin can fill in to add purchase data, these can be seen in the following picture 9 .

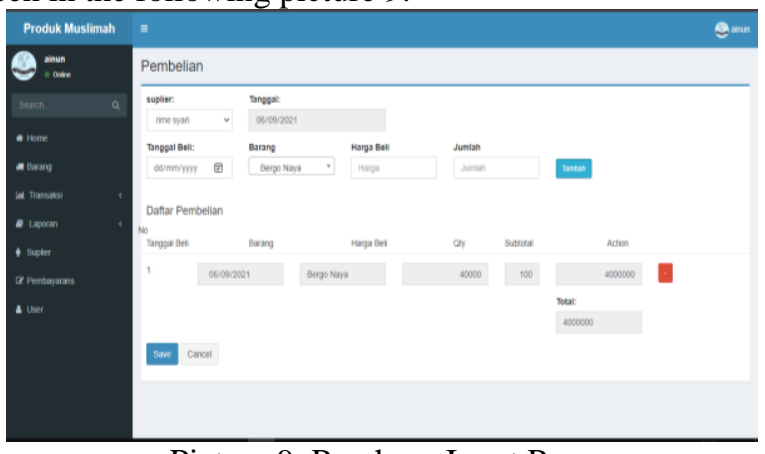

Picture 9. Purchase Input Page

f) Purchase Data Page

The purchase page is the page after the admin inputs the purchase data, this page displays the data that the admin has previously input. This page has several actions 
such as add data, delete data, edit and view data which can be seen in the following picture 10 .

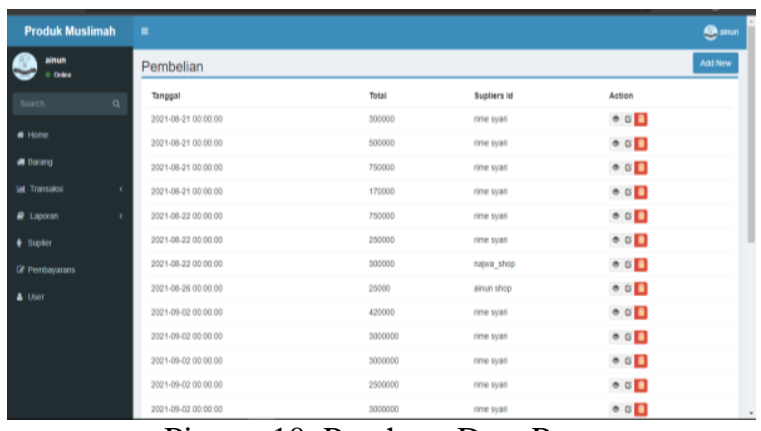

Picture 10. Purchase Data Page

g) Sales Report Page

The sales report page displays sales data which can be seen in the following picture 11 .
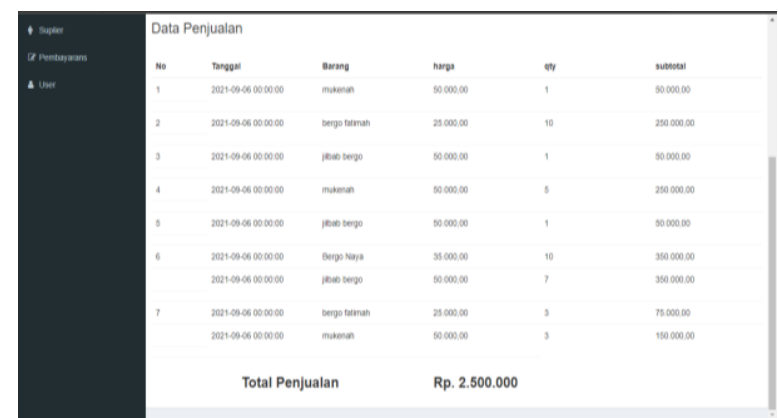

Picture 11. Sales Report Page

h) Purchase Report Page

The purchase report page displays sales data which can be seen in the picture 12 .

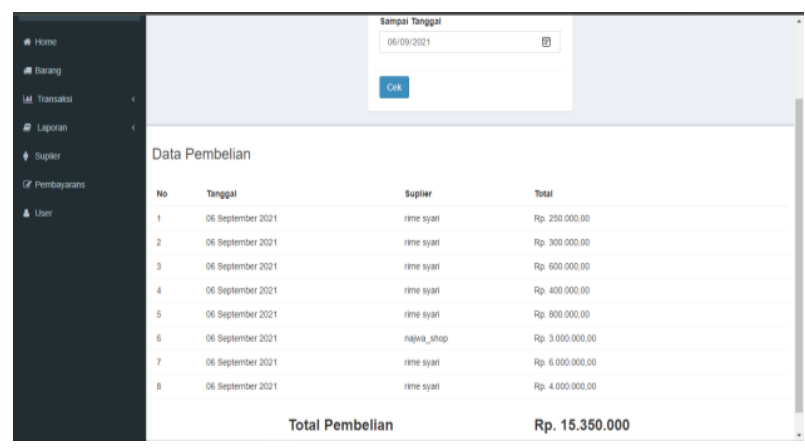

Picture 12. Purchase Report Page

2. E-commerce display

a) E-commerce Home Page Display

The e-commerce page design display is an ecommerce home display which can be seen in the following picture 13 .

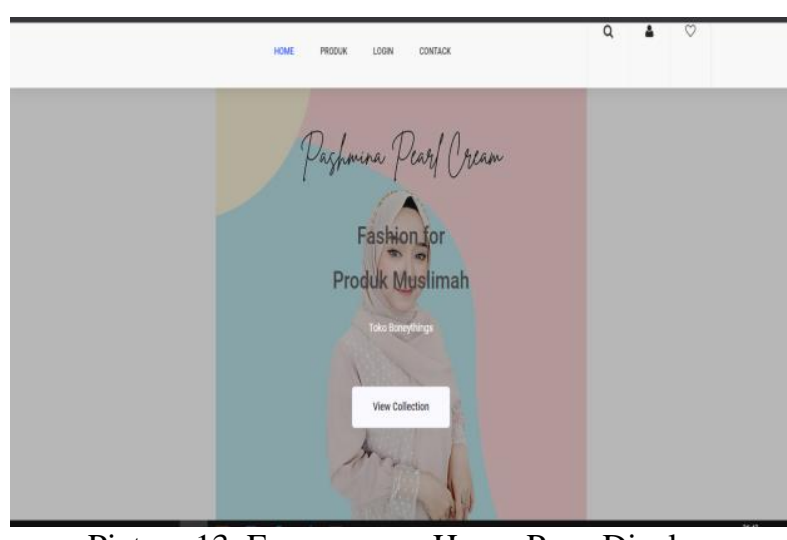

Picture 13. E-commerce Home Page Display

b) Product Page View

The product page display displays several items that can be ordered, which can be seen in the following picture 14 .

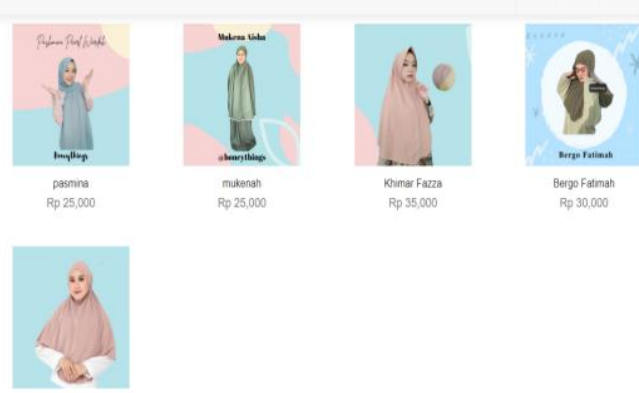

Picture 14. Product Page View

\section{c) Cart Page View}

The cart page display is the main display for placing an order/checking out items that have been entered in the cart which can be seen in the following picture 15 .

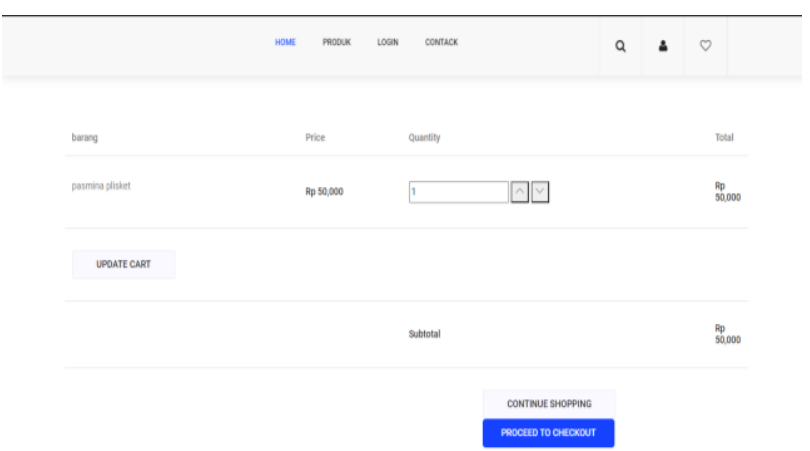

Picture 15. Cart Page View

d) Check Out Page View

The Check Out page display is the main display for placing an order/Check Out the goods that have been entered in the basket and the shipping address page display for sending goods to the desired address that has been ordered which can be seen in the following picture 16. 


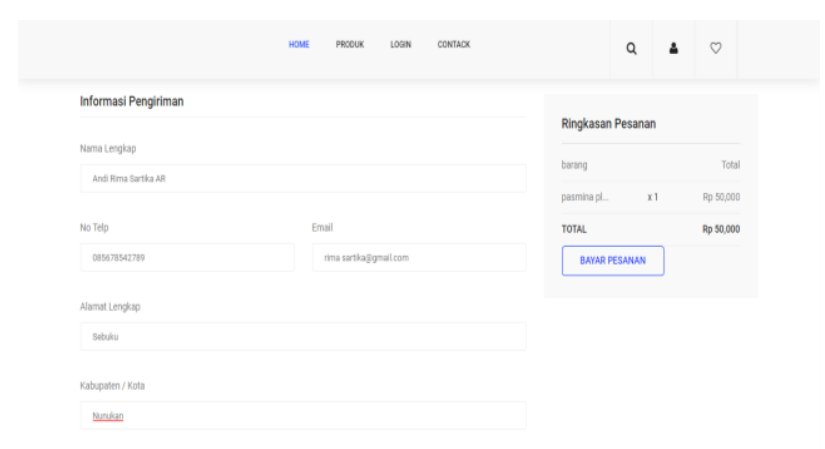

Picture 16. Check Out Page View

e) Shipping Page Display

The display of the goods delivery page is the order information for the goods that have been ordered, which can be seen in the following picture 17 .
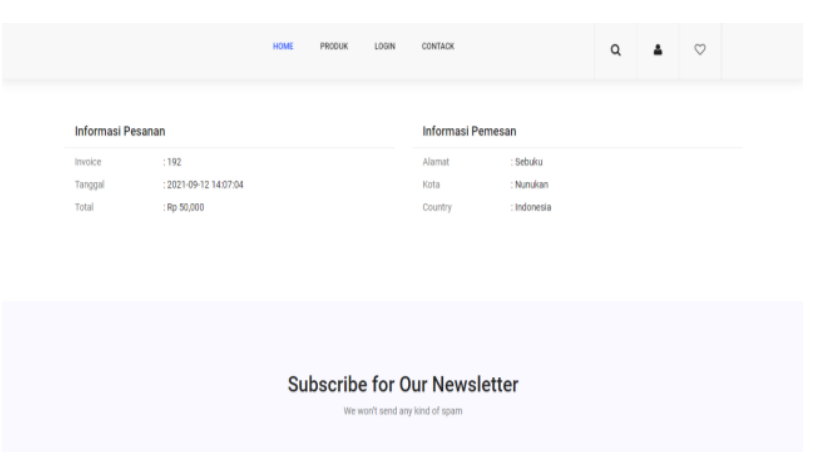

Picture 17. Shipping Page $\overline{\text { Display }}$

\section{CONCLUSIONS}

Based on the results and discussions that have been presented as well as the results and analysis of the design and development of an e-commerce application for selling Muslim equipment at a web-based Boneythings store. This application is a tool for admins and users in processing web-based sales and purchase transaction data for Muslim products.

This application has nine main menus in the admin, namely: home, goods, sales transactions, purchase transactions, purchase reports, sales reports, suppliers, payments, users. And this application has a main menu in the user, namely: Order Items, Cart, Payments..

This application that is built can overcome errors in the calculation of sales transactions and purchases of Muslim products and can produce accurate information in the form of monthly financial reports

\section{REFERENCES}

Abimanyu, E. R. (2020). Aplikasi E-Commerce Business To Customers Pada Ud. Sinar Mulya Business To Customers.

Apriliah, W., Subekti, N., \& Haryati, T. (2021). Penerapan Model Waterfall Dalam Perancangan Aplikasi Sistem Informasi Simpan Pinjam Pada Koperasi Pt. Chiyoda Integre Indonesia Karawang. Jurnal Interkom: Jurnal Publikasi Ilmiah Bidang
Teknologi Informasi Dan Komunikasi, 14(2), 3442. Https://Doi.Org/10.35969/Interkom.V14i2.69

Budyastuti, Suryadharma Dan T. (2019). Sistem Informasi. 6-23.

Burhanudin, B. (2017). Aplikasi E-Commerce Pada Toko Khairunniswa Berbasis Web. Jurnal Sistem Informasi Dan Teknik Komputer, 2(1), 7-13.

Haerulah, E., \& Ismiyatih, S. (2017). Aplikasi ECommerce Penjualan Souvenir Pernikahan Pada Toko “Xyz .” 4(1), 43-47.

Hamdani, A. U. (2020). Penjualan Online Berbasis ECommerce Pada Toko Adhizzshop Dengan Menggunakan Woocommerce. Idealis : Indonesia Journal Information System, 3(1), 26-33.

Jusmawati. (2017). Aplikasi E-Commerce Pada Stand Ifa Kota Merauke. 2(1), 14-20.

Novita, D., Onu, S., Studi, P., Rekayasa, T., \& Lunak, P. (2019). Activity Diagram.

Puspitasari, D. (2016). Sistem Informasi Perpustakaan Sekolah Berbasis Web. Jurnal Pilar Nusa Mandiri Vol. Xii, 12(2), 227-240.

Yusriyanah, E., \& Prihandi, I. (2019). Aplikasi ECommerce Petshop Berbasis Web Dengan Metode Incremental ( Studi Kasus Puri Vet Kembangan ) Pendahuluan Studi Literatur Metodologi. 1(3), 6773. 